\title{
Building Information Modelling Execution in Administrative and Commercial Spaces in Iran - A Fuzzy-Delphi Criteria Prioritization
}

\author{
Behrouz NEMATI ${ }^{*}$, Sara ZANDI ${ }^{* *}$, Babak AMINNEJAD², Mahsa DAVARAZAR1, Yahya \\ SHEIKHNEJAD3, Dina JAHANIANFARD1, Amid MOSTAFAIE4 \\ ${ }^{*}$ Corresponding author \\ ** The author has the same share as the first author \\ ${ }^{1}$ University of Aveiro, Department of Environment and Planning, Aveiro, PORTUGAL \\ ${ }_{2}^{2}$ Islamic Azad University, Department of Civil Engineering, Roudehen Branch, Tehran, IRAN \\ 3 University of Aveiro, Department of Mechanical Engineering, Centro de Tecnologia Mecânica e Automação (TEMA), Aveiro, \\ PORTUGAL \\ 4 University of Aveiro, Department of Biology, Aveiro, PORTUGAL \\ E-mail: behrouz.nemati@ua.pt, sara.zandi@ua.pt,aminnejad@riau.ac.ir,m.davarazar@ua.pt, yahya@ua.pt,dinaj@ua.pt, \\ amid.mostafaie@ua.pt
}

DOI: $10.24193 /$ JSSPSI.2020.6.03

https://doi.org/10.24193/JSSPSI.2020.6.03

K e y w o r d s: Building Information Modelling (BIM), Fuzzy-Delphi, office spaces, commercial spaces, construction projects

\begin{abstract}
A B S T RA C T
Building information modelling (BIM) is considered an innovative approach which is under development all over the world in architecture, engineering, and construction fields. Iran, among the developing countries, has the potential to adapt itself to achieve sustainable development, especially in building construction industry. Thus, this country is selected as the target of this research. In developing countries such as Iran, the construction industry is currently on progress, but in our best knowledge, there is no evidence for the effective and commercialized execution of BIM yet. The final aim of BIM application would be to make public and private projects more sustainable. Hence, in order to push this technology forward and provide more sustainable conditions for developing countries, such as Iran, this study emphasizes the main challenges and obstacles in the utilization of BIM in the construction industry. A FuzzyDelphi questionnaire was designed in order to acquire consensus among the scientific community about the criteria that may affect the implementation of BIM in constructions. The questionnaire was then analyzed by using SPSS (25.0). Results clearly demonstrated that the time required for BIM designing step, along with associated costs and lack of motivation among the involved parties are the main obstacles preventing the commercialized implementation of BIM in the construction projects.
\end{abstract}

\section{INTRODUCTION}

The first step towards sustainable building construction is to develop the architecture patterns and the construction industry in compliance with Building Information Modelling (BIM). BIM can be defined as a process used in the construction phase, which provides a management system of graphical data and information together with the full description of a given construction project by modelling and simulation of all the involving objects (Garyaeva, 2018; Reizgevičius et al., 2018; Zhao et al., 2017). 
Considering the high costs involved in building and exploiting office and commercial spaces, as a main part of construction in any city (Rehm and Ade, 2013), BIM can play an important role in economic growth when used by the involved parties at large scales. On the other hand, energy consumption is one of the most important issues of recent studies, which has been discussed in various sections (Jahanshahi et al., 2019). BIM can be a helpful tool in many areas, namely energy management (Abanda and Byers, 2016). The strategic decision to implement such a new tool is directly related to the potential benefits, which the technique is likely to bring, and the attributed costs (Takim et al., 2013). BIM is considered a new process developed in architecture, engineering, and construction (AEC) activities in order to create virtual models of various building parts such as walls, floors, etc, as well as building materials by using numerical, textual and imagery data to detect the probable problems prior to construction. In this process, building parts are characterized by various numerical parameters such as dimensions (Pocobelli et al., 2018). Despite the importance of BIM in designing building structures, few studies have been performed on the application of this technique in real situations (Bosch-Sijtsema et al., 2019). In Iran, BIM has not yet been extensively implemented. The construction industry in Iran pays very little attention to BIM. This may raise a lot of issues for the construction industry in this country, in the future. Recent studies and the gathered information show that Iran's construction industry has significantly lacked this technology (Hosseini et al., 2018). The use of traditional and old methods in Iran have led to a lot of costly construction and eventually caused the inevitable delay in the delivery of the project. Most of the activists in this field have prevented the implementation of this technique by ignoring its benefits (Khanzadi et al., 2018).

It is worth mentioning that the effective implementation of BIM requires developing the relevant tools, protocols, and standards (Akponeware and Adamu, 2017). In this regard, there are some experiences in some developed and developing countries that can be used to facilitate the implementation of BIM. It has been also shown that there is a direct relation between the development level of the countries and the extent of BIM implementation (Jung and Lee, 2015). For instance, in China, many professional consulting companies are now providing consulting services on BIM, bringing a number of advantages such as optimization and minimizing the engineering costs as well as the reduction in the construction time (Herr and Fischer, 2019; Zhang et al., 2016). Although these advantages may also cause the application of BIM in reconstruction projects, BIM has not been sufficiently employed in such projects, specifically in developing countries (Pavlovskis et al.,
2017). Various pieces of software have been already developed to facilitate the application of BIM. Autodesk Revit is one of the most popular software in this regard (Ferrandiz et al., 2018). All details in the Revit have multi-dimensional design capabilities and Fig. 1 (a and b) reveals a design example and virtualization of a building facade in Revit (Mostafavi et al., 2015). As it can be observed from Fig. 1, the provided model with BIM (a), includes all the details which have further been implemented in the constructed building.
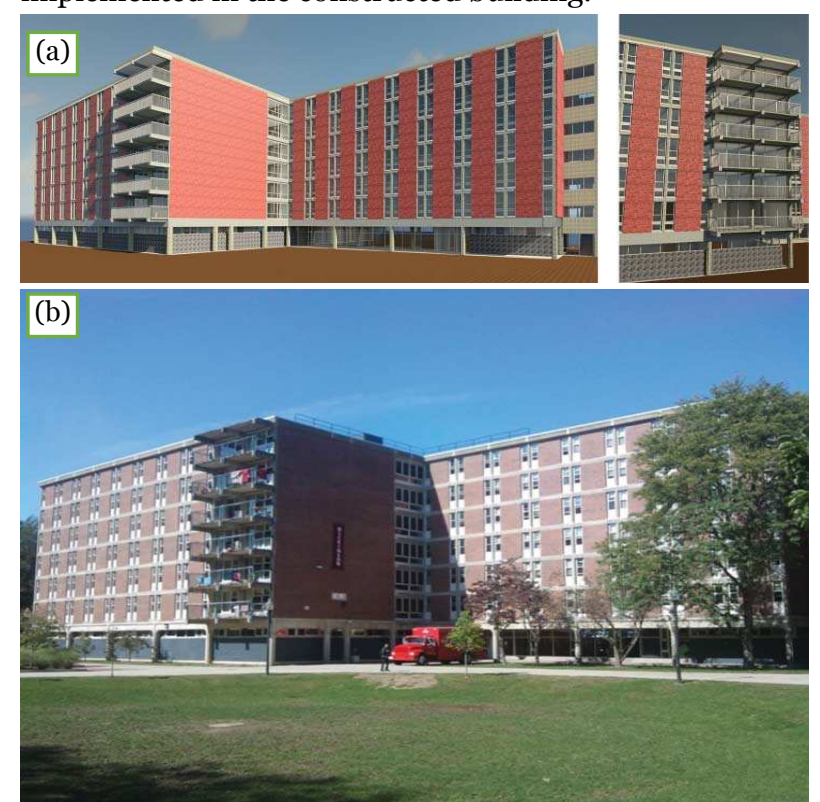

Fig. 1. Grayson House's geometry drawn in Autodesk Revit (a) Orchard Hill residential area (b) (Mostafavi et al., 2015).

The Fuzzy-Delphi methodology, as a useful tool for reaching consensus among the experts in the field (Jahanshahi et al., 2019; Kamali et al., 2015; Kamali et al., 2017) was used in this study in order to identify and rank the most important criteria influencing the implementation of BIM in building and construction activities. According to the criteria identified and prioritized, the main barriers and obstacles of BIM employment were critically addressed.

\section{THEORETICAL BACKGROUND}

Since the beginning of the 2000s, the AEC industry started to adopt BIM in projects (Succar, 2009). Various countries all over the world have contributed effectively to the rapid development and implementation of this tool. In a scientometric study covering the published papers between 2005 and 2016, Zhao et al. (2017) indicated that the United States (196 articles), South Korea (95 articles), China (71 articles), Australia (63 articles), and the United Kingdom (54 articles), had the highest research contributions in BIM globally. They also stated that currently there is a general lack of attention in the developing countries. In 
this study, some countries (Pakistan, Vietnam, Mongolia, Sri Lanka, Myanmar, Thailand, Indonesia, Malaysia, India) were taken under examination. In developing countries, especially in Asia, BIM technology has been underestimated. However, most of the above-mentioned countries have accepted the benefits of its implementation. Much more, challenges and obstacles to the implementation of BIM require considerable attention (Ismail et al., 2017). To examine the keywords development from 2005 to 2016, the scientometric method was applied. Fig. 2 is the output of the program Cite Space to represent this matter. A detailed analysis of the keywords used in the literature for BIM can also demonstrate a developing trajectory regarding the frequency of utilization in the literature. Keywords, such as "Building Information Modelling", "building information modelling" and "BIM", were merged over time into "building information modelling (BIM)" (Fig. 2). BIM was reviewed in several areas such ashistorical building management (Rodrigues et al., 2019), transportation infrastructure (Costin et al., 2018), bridge design and construction, construction management of railway tunnel (Chen, 2018), building and design of water supply and drainage (Wei et al., 2017), etc. All of the above-mentioned studies argue in favour of BIM.

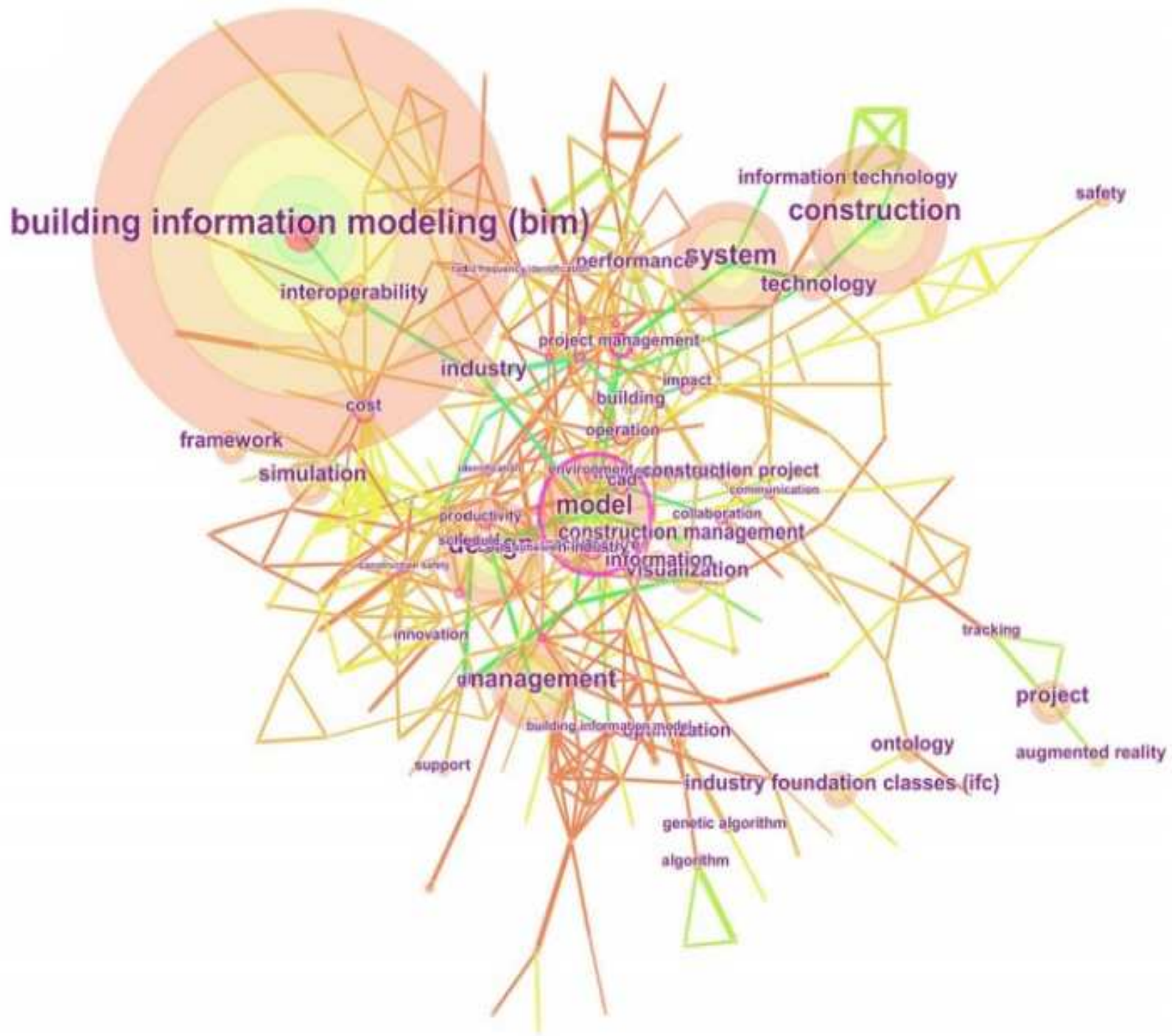

Fig. 2. The network of co-occurring keywords used in BIM research in the literature (2005-2016), with 278 nodes and 770 links, reprinted with permission of Zhao et al. (2017).

On the topic of this paper, there have been some studies in different countries to assess the conditions of their construction industries. Therefore, in Japan, architectural companies and general contractors, asproject customers, were not aware of the value using BIM in projects (Kaneta et al., 2017). In another executed study, soft and technical sections have proved to have a great influence on the use of BIM. For example, the Dutch trade associations were struggling to achieve this goal (Siebelink et al., 2018).

Over the past few years, BIM benefits have been acknowledged among private and public owners 
around the world. Even some governments spend a lot of money on developing this technology (Liao and Teo, 2019). It is of high importance to analyze the reasons, causing these countries to apply this technique less, thus, more research is required in this regard. In Iran, the lack of attention to BIM is noted and traditional techniques are still popular in the construction industry (Hosseini et al., 2016).

\section{METHODOLOGY}

\subsection{Identification of criteria and sub-criteria}

In this study, based on literature screening, some 15 criteria were identified for the development of BIM application in administrative and commercial construction projects in Iran (Table 1).

Table 1. Identified criteria and sub-criteria.

\begin{tabular}{|c|c|c|c|}
\hline Criteria & Sub-Criteria (Definition/ Description) & Identification & References \\
\hline \multirow{7}{*}{ Technical } & $\begin{array}{l}\text { 1- Insufficient knowledge on BIM enforcement } \\
\text { systems in the senior executives. }\end{array}$ & CR1 & (Kaneta et al., 2017) \\
\hline & 2- Lack of sufficient research projects on BIM & $\mathrm{CR} 2$ & (Zhao et al., 2017) \\
\hline & 3- Lack of experts in the field of BIM & CR3 & $\begin{array}{l}\text { (Krivonogov et al., 2018; Migilinskas et al., 2013; } \\
\text { Pavlovskis et al., 2017; Migilinskas et al., 2017) }\end{array}$ \\
\hline & 4- Lack of BIM training centers & CR4 & (Krivonogov et al., 2018) \\
\hline & $\begin{array}{l}\text { 5- Incompatibility of the existing software and } \\
\text { hardware with BIM software system }\end{array}$ & CR5 & (Mirarchi et al., 2018) \\
\hline & $\begin{array}{l}\text { 6- Lack of proper training programs for the } \\
\text { personnel to become familiar with BIM }\end{array}$ & CR6 & (Krivonogov et al., 2018; Garyaeva, 2018) \\
\hline & $\begin{array}{l}\text { 7- Insufficient information on BIM among the } \\
\text { private sector }\end{array}$ & CR7 & (Kaneta et al., 2017) \\
\hline \multirow{6}{*}{ Social } & $\begin{array}{l}\text { 8- Lack of incentives in governmental } \\
\text { organizations to enforce BIM's performance factors }\end{array}$ & CR8 & (Kaneta et al., 2017) \\
\hline & $\begin{array}{l}\text { 9- Distrust of construction companiesinBIM } \\
\text { efficiency }\end{array}$ & CR9 & (Kaneta et al., 2017; Galieva et al., 2018) \\
\hline & $\begin{array}{l}\text { 10- Distrust of consulting engineersinBIM } \\
\text { efficiency }\end{array}$ & CR10 & $\begin{array}{l}\text { (Reizgevičius et al., 2018; Kaneta et al., 2017; Galieva et } \\
\text { al., 2018) }\end{array}$ \\
\hline & $\begin{array}{l}\text { 11- Distrust of construction contractors inBIM } \\
\text { efficiency }\end{array}$ & CR11 & (Kaneta et al., 2017; Galieva et al., 2018) \\
\hline & $\begin{array}{l}\text { 12- Lack of transparency regarding BIM positive } \\
\text { results with private sector activists }\end{array}$ & CR12 & (Kaneta et al., 2017; Galieva et al., 2018) \\
\hline & $\begin{array}{l}\text { 13- Unwillingness of contracting companies to use } \\
\text { BIM system }\end{array}$ & CR13 & (Kaneta et al., 2017) \\
\hline Economic & 14- High costs of purchasing BIM-related software & CR14 & (Kaneta et al., 2017) \\
\hline Timing & 15- Lack of time to implement BIM & CR15 & (Kaneta et al., 2017) \\
\hline
\end{tabular}

A professional questionnaire (see supplementary information) was elaborated based on these criteria and then employed to assist in collecting the opinion of a target expert group. The expert group was carefully selected by inviting experts in the field, with excellent academic and/or practical experience in the field of BIM. A total of 21 responses were received and analyzed to achieve the results of this study.

\subsection{Fuzzy-Delphi Method}

Delphi is one of the most popular methodology implemented so far for the identification and prioritization of the criteria and sub-criteria influencing a process (Okoli and Pawlowski, 2004; Kamali et al., 2017).

This method is normally implemented through summarizing expert opinions in a specific scientific domain. In the case of Delphi method, the choice of respondents is based on their level of experience and skill onthe subject. Respondents should have enough skill and expertise in the field. In this study, 21 specialists and researchers, construction experts and BIM experts, were selected. The number of respondents varies depending on the subject. In many cases, the Delphi method can be employed with fewer users. However, all respondents should be considered to be experts (Chang et al., 2000; Doyon et al., 1971; Yousuf, 2007). A fuzzy number is normally expressed as a fuzzy set defining a fuzzy interval in the real number $R$, often used to explain the uncertain information in the decision-making process (Ban and Coroianu, 2012).

As a type of fuzzy numbers, a triangular fuzzy number must be represented with three numbers, as follows: $=\left(a_{1}, a_{2}, a_{3}\right)$. The membership functions that can be used to interpret this 
representation, hold the following conditions (Gani and Assarudeen, 2012):

$$
y=m(x)=\left\{\begin{array}{lr}
0 & x<a_{1} \\
\frac{x-a_{1}}{a_{2}-a_{1}} a_{1} \leq x \leq a_{2} \\
\frac{a_{3}-x}{a_{3}-a_{2}} a_{2} \leq x \leq a_{3} \\
0 & x>a_{3}
\end{array}\right\} \text { Eq. } 1
$$

A number of reports exist in the literature for the effective application of the fuzzy-Delphi methodology for making sustainable decisions in various scientific fields (Hsu et al., 2010; Sánchez-Lezama et al., 2014; Tahriri and Mousavi, 2014). In the present study, the fuzzy-Delphi method was used in order to distinguish the criteria and sub-criteria affecting the implementation of BIM in the AEC industry and, afterwards, we attemped to rank these criteria from the most effective to least ones. According to Table 2, for the construction of the questionnaire, a fuzzy scale including seven linguistic variables and the respective triangular fuzzy numbers were used. The geometric mean (Eq. 2) (Hsu et al., 2010) was used to calculate the fuzzy weights of the criteria, where L, M, and U express the fuzzy number components. Eq. (3) was also used to defuzzy the values. Moreover, all criteria were defuzzied using Eq. (1) and defuzzied numbers were then employed to classify and prioritize the criteria.

$$
\begin{gathered}
L_{j}=\operatorname{Min}_{i}\left\{L_{i j}\right\}, M_{j}=\frac{1}{n} \sum_{i=1}^{n} M_{i j}, U_{j}=\operatorname{Max}_{i}\left\{U_{i j}\right\} \text { Eq. } 2 \\
d f=\frac{1}{4}(L+2 M+U)
\end{gathered}
$$

Table 2. Linguistic variables and the relevant fuzzy scales for the relative importance of the criteria.

\begin{tabular}{|l|r|r|}
\hline $\begin{array}{c}\text { Linguistic } \\
\text { variable }\end{array}$ & $\begin{array}{c}\text { Fuzzy Scale } \\
(\mathbf{L}, \mathbf{M}, \mathbf{U})\end{array}$ & $d f=\frac{1}{4}(L+2 M+U)$ \\
\hline Extremely High & $(0.9,1.0,1.0)$ & 0.975 \\
\hline Very High & $(0.7,0.9,1.0)$ & 0.875 \\
\hline High & $(0.5,0.7,0.9)$ & 0.7 \\
\hline Fair & $(0.3,0.5,0.7)$ & 0.5 \\
\hline Low & $(0.1,0.3,0.5)$ & 0.3 \\
\hline Very Low & $(0.0,0.1,0.3)$ & 0.125 \\
\hline Extremely Low & $(0.0,0.0,0.1)$ & 0.025 \\
\hline
\end{tabular}

\subsection{Analysis of results}

In this research, SPSS v.25.0 was used for data analysis. It must be stated that the data used as the input of the software were the defuzzied numbers received from the expert group. Data were analysed using the descriptiveanalytic method. Cronbach's alpha was used to assess the internal consistency of the answers provided by the experts. The Cronbach alpha coefficient is one of the common methods of measuring internal consistency (reliability), which is usually used to evaluate the reliability of the time scale of the questions (Béland et al., 2016). After reviewing the responses by the software, a coefficient was obtained, describing the correlation between the responses in the questionnaire and the variation between $o$ and 1 , based on the analysis of the responses. With a coefficient close to 1 , the reliability of the indices is higher (Gottems et al., 2018). If the Cronbach's alpha coefficient is calculated higher than 0.7 , it means that data is reliable for analysis (Pinto et al., 2014). The Kolmogorov-Smirnov (KS) test was also used to evaluate the inconsistency of the responses and to verify the normality of the data (Zhang and Chen, 2018). In this manuscript, KS was used in addition to the Shapiro-Wilk test to verify the normality of the collected data, due to the fact that the sample size is less than 2000.

\section{RESULTS AND DISCUSSION}

After the implementation of Fuzzy-Delphi method on the responses of the questionnaire, the results of simulation are depicted in Table 3 and Fig. 3. The numbers shown for every criterion were obtained using the Eq. 2 and 3.

Table 3. Linguistic variables and the relevant fuzzy scales for the relative importance of the criteria.

\begin{tabular}{|l|l|c|r|}
\hline \multirow{5}{*}{ Criteria } & $\begin{array}{c}\text { Sub- } \\
\text { Criteria } \\
\text { identific. }\end{array}$ & $\begin{array}{c}\text { Fuzzy Scale } \\
(\mathbf{L}, \mathbf{M}, \mathbf{U})\end{array}$ & $d f=\frac{1}{4}(L+2 M+U)$ \\
\hline \multirow{5}{*}{ Technical } & CR1 & $(0.0,0.70,1.0)$ & 0.600 \\
\cline { 2 - 4 } & CR2 & $(0.0,0.70,1.0)$ & 0.598 \\
\cline { 2 - 4 } & CR3 & $(0.0,0.74,1.0)$ & 0.621 \\
\cline { 2 - 4 } & CR4 & $(0.0,0.68,1.0)$ & 0.588 \\
\cline { 2 - 4 } & CR5 & $(0.0,0.68,1.0)$ & 0.590 \\
\cline { 2 - 4 } & CR6 & $(0.0,0.64,1.0)$ & 0.569 \\
\cline { 2 - 4 } & CR7 & $(0.0,0.70,1.0)$ & 0.602 \\
\hline \multirow{5}{*}{ Social } & CR8 & $(0.0,0.65,1.0)$ & 0.576 \\
\cline { 2 - 4 } & CR9 & $(0.0,0.74,1.0)$ & 0.619 \\
\cline { 2 - 4 } & CR10 & $(0.1,0.72,1.0)$ & 0.635 \\
\cline { 2 - 4 } & CR11 & $(0.0,0.71,1.0)$ & 0.605 \\
\cline { 2 - 4 } & CR12 & $(0.1,0.76,1.0)$ & 0.656 \\
\cline { 2 - 4 } & CR13 & $(0.0,0.77,1.0)$ & 0.636 \\
\hline Economic & CR14 & $(0.1,0.81,1.0)$ & 0.680 \\
\hline Timing & CR15 & $(0.3,0.79,1.0)$ & 0.720 \\
\hline
\end{tabular}

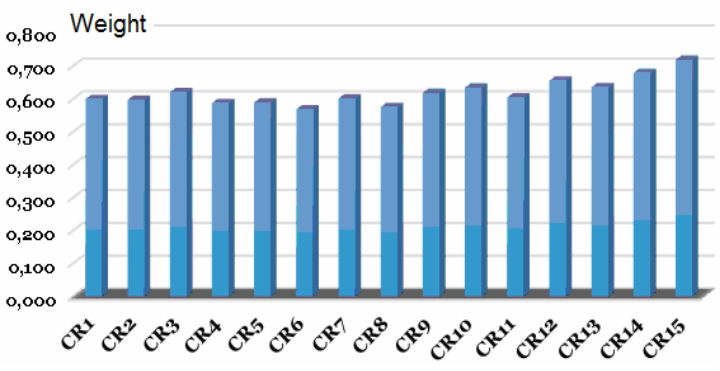

Fig. 3. Calculated weights of the criteria and sub-criteria for the development of BIM in AEC.

Table 4 presents the results of the consistency test by the Cronbach's Alpha achieved 
after analysis of the responses in SPSS. Results indicated that the responses with the Cronbach's Alpha $=0.792$ were considered to be consistent and reliable. KolmogorovSmirnov and Shapiro-Wilk tests were also used to evaluate the normality of data. As shown in Table 5 , all the outputs had values of less than 0.05. Hence, the obtained responses were determined to be nonnormalized and non-parametric.

Table 4. Case processing summary (SPSS 25.0 software).

\begin{tabular}{|r|l|r|r|r|r|}
\hline \multicolumn{2}{|c|}{ Analysi } & N & (\%) & No. of Items & Cronbach's Alpha \\
\hline \multirow{3}{*}{ Cases } & Valid & 21 & 100 & 15 & \\
\cline { 2 - 7 } & Excluded & 0 & 0 & 0 & 0.792 \\
\cline { 2 - 7 } & Total & 21 & 100 & 15 & $\mathbf{0 . 7 9 2}$ \\
\hline
\end{tabular}

Table 5. Normality test results.

\begin{tabular}{|c|c|c|c|c|c|c|}
\hline \multicolumn{3}{|c|}{ Shapiro-Wilk } & \multicolumn{3}{|c|}{ Kolmogorov-Smirnov } & \multirow{2}{*}{ Criteria } \\
\hline Sig. & df & Statistic & Sig. & df & Statistic & \\
\hline 0.002 & 21 & 0.830 & 0.002 & 21 & 0.248 & CR1 \\
\hline 0.010 & 21 & 0.871 & 0.002 & 21 & 0.243 & $\mathrm{CR} 2$ \\
\hline 0.000 & 21 & 0.783 & 0.001 & 21 & 0.249 & CR3 \\
\hline 0.005 & 21 & 0.852 & 0.001 & 21 & 0.261 & CR4 \\
\hline 0.000 & 21 & 0.790 & 0.001 & 21 & 0.259 & CR5 \\
\hline 0.008 & 21 & 0.867 & 0.001 & 21 & 0.257 & CR6 \\
\hline 0.009 & 21 & 0.868 & 0.014 & 21 & 0.213 & CR7 \\
\hline 0.020 & 21 & 0.887 & 0.014 & 21 & 0.212 & CR8 \\
\hline 0.000 & 21 & 0.753 & 0.000 & 21 & 0.291 & CR9 \\
\hline 0.039 & 21 & 0.903 & 0.041 & 21 & 0.192 & CR10 \\
\hline 0.001 & 21 & 0.809 & 0.001 & 21 & 0.264 & CR11 \\
\hline 0.003 & 21 & 0.841 & 0.000 & 21 & 0.285 & CR12 \\
\hline 0.000 & 21 & 0.782 & 0.000 & 21 & 0.309 & CR13 \\
\hline 0.000 & 21 & 0.782 & 0.000 & 21 & 0.313 & CR14 \\
\hline 0.008 & 21 & 0.864 & 0.003 & 21 & 0.237 & CR15 \\
\hline
\end{tabular}

Considering that the sum of responses was non-parametric, the Kruskal-Wallis test was also used to verify the uniformity of the perceptions of the respondents. Table 6 presents the achieved results. The output of the test was calculated to be 0.535 , which is higher than the threshold (0.05) and, thus, the perceptions of the respondents about the criteria are almost identical and there is almost no difference in the clearness of questions, which means that all respondents have gotten the same impression from the questionnaire. This test was used to compare the average of two or more than two groups of samples. The assumptions in this test are based on the statistical comparison of the existence or absence of differences between groups and according to the responses. The value of the number is 0.05 , which means that if the output of the program for this test is less than that, then, there is a difference between the groups of the respondents (Maimaiti et al., 2019).

Table 6. Kruskal-Wallis Test (SPSS 25.0 software).

\begin{tabular}{|l|r|}
\hline \multicolumn{1}{|c|}{ Test Statistics } & \multicolumn{2}{|c|}{ Answer } \\
\hline Kruskal-Wallis H & 12.891 \\
\hline df & 14 \\
\hline Asymp. Sig. & 0.535 \\
\hline
\end{tabular}

Table 7 and Fig. 4 present the final ranking of the mentioned sub-criteria. Based on the results achieved, "the lack of time to implement BIM" was identified as the most important parameter while the "lack of proper training programs for the personnel to become familiar with BIM" was identified as having the minimum impact on the development of BIM in developing countries like Iran.

The absence or lack of familiarity with BIM software and hardware, the lack of adequate training and insufficient and costly data were investigated in a study in Malaysia (Mohammad et al., 2018); in another study, the lack of familiarity and trust of employers, designers and contractors in BIM and also the required time to design BIM have been investigated (Migilinskas et al., 2017). However, the ranking of criteria from the least to most significant is in compliance with the listed order in the table based on the situation of the constructing industry in Iran. By the comparison among different executed studies in different countries, it can be comprehended that the ranking criteria utilized in all studies in literature are similar, while the significance that they are given varies from one country to another. According to experts' opinions, the lack of time for the implementation of BIM is the most important obstacle for the use of BIM method in Iran, 
and specifically in administrative and commercial projects in Iran. In design phase, more time must be devoted if BIM method is added to this process, but, as it has been proven repeatedly, it will result in shorter time at the project operation stages. One of the reasons is the elimination of interferences and operational barriers resulting from overlapping of various design sectors. For instance, the facilities designed by the consulting engineers can interfere with the designed structure, which is a frequently occurring problem in the construction projects, and if the problem could be predicted at the pre-design stage by the software and the as-built drawings were redesigned based on the relevant solutions, the operations would not be interrupted. Consequently, the project would not be needed to be rescheduled even during the operational stage. Hence, while observing the whole project, required construction time is shortened in case BIM is implemented. The time consumed in the design stage via the utilization of BIM method is considerably shorter compared to the time spent on interruptions during the constructing procedure.

Table 7. Final ranking of the studied sub-criteria.

\begin{tabular}{|l|r|r|r|}
\hline \multicolumn{1}{|c|}{ Sub-Criteria } & Identification & \multicolumn{1}{|c|}{$\begin{array}{c}\text { De-Fuzzy } \\
\text { values }\end{array}$} & Rank \\
\hline Lack of time to spend for BIM implementation & CR15 & 0.720 & 1 \\
\hline High costs of purchasing BIM-related software & CR14 & 0.680 & 2 \\
\hline Lack of transparency regarding BIM positive results with private sector activists & CR12 & 0.656 & 3 \\
\hline Unwillingness of contracting companies to use BIM system & CR13 & 0.636 & 0.635 \\
\hline Distrust of consulting engineers inBIM efficiency & CR10 & 0.621 & 5 \\
\hline Lack of experts in the field of BIM & CR3 & 0.619 & 6 \\
\hline Distrustof construction companies in BIM efficiency & CR9 & 0.605 & 7 \\
\hline Distrust of construction contractors in BIM efficiency & CR11 & 0.602 & 8 \\
\hline Lack of sufficient information on BIM among the private sector & CR7 & 0.600 & 9 \\
\hline Insufficient knowledge of senior executives on BIM enforcement systems & CR1 & 0.598 & 10 \\
\hline Insufficient research projects on BIM & CR2 & 0.590 & 11 \\
\hline Incompatibility of the existing software and hardware with BIM software system & CR5 & 12 \\
\hline Lack of BIM training centers & CR4 & 0.588 & 13 \\
\hline $\begin{array}{l}\text { Insufficient incentives to enforce BIM's performance factors in governmental } \\
\text { organizations }\end{array}$ & CR8 & 0.576 & 14 \\
\hline Lack of proper training programs for the personnel to become familiar with BIM & CR6 & 0.569 & 15 \\
\hline
\end{tabular}

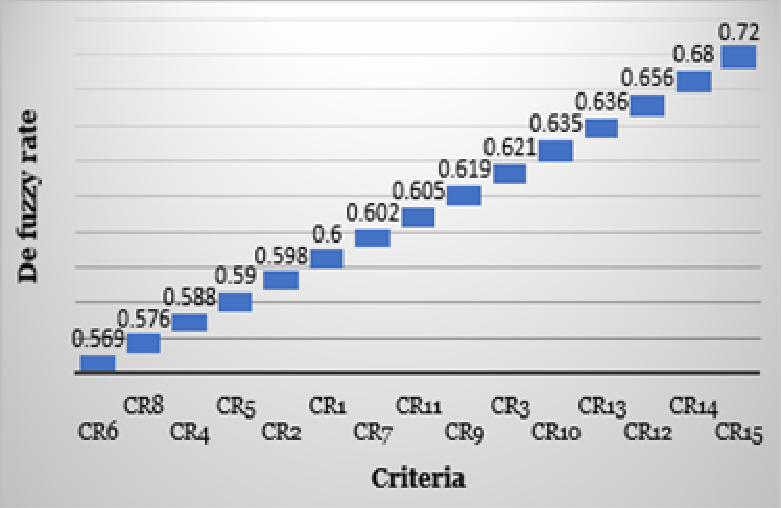

Fig. 4. Final ranking of the criteria.

BIM has a significant potential to improve the productivity and efficiency of civil engineering at all construction stages. Management of facilities and elimination of barriers to enhance the performance and utilization of the existing technologies in computer design are among its main advantages. This model has a communicating database that can hold all the information even after the construction phase and during the time that the building is accommodated, enabling it to create a mechanism for a wide-range collaboration among designers, engineers, constructors and facility managers. Another aspect of BIM is that information is put together once and it prevents its repetition, resulting in fewer errors, greater compliance, clarity, accuracy, and ultimately saving time (Kivits and Furneaux, 2013). All of these explanations illustrate the significant effects of this method in the prevention of time-wasting procedures and repetition of operations at the implementation stage.

The high costs of purchasing BIM-related software, was ranked second among the studied criteria. The relevant software and related hardware are expensive; meanwhile, one of the biggest advantages of BIM method is cost-saving throughout the project. What should be considered is whether the costs of purchasing software and hardware by the consulting companies are comparable to the possible cost-savings provided by this method. The advantageous application of BIM to eliminate the occurrence of unpredicted incidents, which most likely trigger delays in the 
construction process and supplementary expenses, is considered to compensate, cost-wise, for the investments in its relevant and costly software and hardware. However, the lack of acquaintance with BIM concept and its advantages among stakeholders can be a reason for of the low level of willingness towards using it. We have to keep in mind that the recent advancements in BIM technology provide a starting point to develop significant solutions, specifically, in planning and management (Enshassi et al., 2016).

The third-ranked criterion in the questionnaire was devoted to the lack of transparency about the positive results of BIM for the private sector activists. Improvement in the construction industry is one of the most important factors in the development of developing countries. Naturally, any method that can pave the way of development should be welcome. However, having uncertainty about the new methods will make them less attractive. On the other hand, in order to make them more attractive, the advantages of these methods should be more clearly presented. This has forced activists to employ BIM method by acknowledgement of its effectiveness and positive outcomes. Nevertheless, BIM is not as popular as it is expected in many developing countries, especially in Asia (Ismail et al., 2017). The fourth rank criterion among the considered criteria is the contracting companies' unwillingness towards BIM implementation. One of the biggest barriers on the way of BIM acceptance is the lack of demand. Some of the most important users of this method are the contractors. It should be taken into account that when BIM advantages are widely introduced to stakeholders, private sector customers of BIM will also increase (Chan, 2014).

Ranked fifth among the criteria is the disbelief of designers and consultant engineers in BIM. The designers have an important role in representing the various aspects of new construction technologies, but first, they should have enough motivation to develop, extend, and accept the risks regarding the useof new methods. This can be materialized by a better understanding of the advantages of this method and the advancements in technology. Contractors must understand that, during the construction period, increasing the productivity of BIM is necessary, and providing reliable information for better decisionmaking processes can be a major contribution to progress (Lin et al., 2018).

It should be noted that there are some other factors and criteria analysed in the questionnaire such as: 1 - the lack of experts and expertise in BIM, 2 - the disbelief of construction companies and contractors in the effectiveness of BIM, 3 - insufficient information on BIM in the private sector, 4 - lack of knowledge on BIM operational systems specifically among the executives,
5 - insufficient research projects on BIM relative to other research areas and articles in Iran, 6 - inconsistency of software and hardware in companies and organizations with BIM software systems, 7 - lack of BIM professional training centers outside offices and companies, 8 - lack of motivation on behalf of government agencies to implement BIM and lack of regulation regarding its implementation in subordinated institutions, and finally, 9 - lack of suitable training programs for the personnel to make them familiar with the BIM.

It proves difficult to change the mindset of the private sector, and this has made operational users avoid the use of BIM. On the other hand, the government should be the largest user in the construction industry, and if the BIM demand increases on the governmental side, it will ultimately expand to the construction community, as well. In general, barriers to the BIM can be divided into management barriers and training barriers, which are mostly related to the lack of knowledge and technology. As discussed, the lack of information onthe BIM has resulted in misunderstanding or underestimation of BIM potential and advantages (Muller et al., 2016). In the end, by considering all the studied criteria, Iran may also exploit the promising advantages of BIM in close future. In fact, governmental incentive plans as well as holding technical class for engineers for free may help in this regard.

\section{CONCLUSIONS}

BIM is a new methodology in the construction area, which designs and implements the project in multidimensional software to fix probable issues, deficiencies and interferences and, finally, to achieve a coherent comprehensive design with the least possible defects. This method has been accepted in the developed countries and it is considered as one of the main factors in the construction projects; however, in the developing countries, this methodology has been insufficiently employed. The present paper studies the causes and factors that have prevented the commercialized use of BIM technique in Iran, especially in the construction of the administrative and commercial complexes. This was performed by a questionnaire that was distributed among the experts and researchers of this area. According to the experts, additional time needed at the designing level, a high cost of purchasing equipment, and lack of information on various advantages of BIM among users in the private sector and construction contractors, were the most important barriers. Moreover, it was comprehended that, by combining the educational and incentive plans as well as highlighting all benefits of the application of this method for all engaged people, the path towards productive and efficient building 
construction will be paved. In addition, in the public sector, the endorsement of relevant regulations in the construction system of the country and promoting enough investments in this area can prevent the waste of valuable resources at the national scale.

\section{REFERENCES}

Abanda F. H., Byers L. (2016), An investigation of the impact of building orientation on energy consumption in a domestic building using emerging BIM (Building Information Modelling). Energy, 97: 517-527. DOI: https://doi.org/10.1016/j.energy.2015. 12. 135

Akponeware A. O., Adamu Z. A. (2017), Clash Detection or Clash Avoidance? An Investigation into Coordination Problems in 3D BIM. Buildings 7(3): 128. DOI: https://doi.org/10.3390/buildings7030075

Ban A. I., Coroianu, L. (2012), Nearest interval, triangular and trapezoidal approximation of a fuzzy number preserving ambiguity. International Journal of Approximate Reasoning, 53: 805-836. DOI: https://doi.org/10.1016/j.ijar.2012.02.001

Béland S., Pichette F., Jolani S. (2016), Impact on Cronbach's Alpha of Simple Treatment Methods for Missing Data. The Quantitative Methods for Psychology 12(1): 57-73. DOI: 10.20982/tqmp.12.1.po57

Bosch-Sijtsema P. M., Gluch P., Sezer A. A. (2019), Professional development of the BIM actor role. Automation in Construction, 97: 44-51. DOI: https://doi.org/10.1016/j.autcon.2018.10.024

Chan C. T. W. (2014), Barriers of Implementing BIM in Construction Industry from the Designers' Perspective: A Hong Kong Experience. Journal of System and Management Sciences, 4(2): 24-40. Retrieved from http://www.aasmr.org/jsms/Vol4/ No.2/JSMS_VOL4_NO2_003.pdf

Chang P. T., Huang L. C., Lin H. J. (2000), The fuzzy Delphi method via fuzzy statistics and membership function fitting and an application to the human resources. Fuzzy Sets and Systems 112: 511-520. DOI: https://doi.org/10.1016/So165-0114(98)00067-0

Chen F. (2018), Application of BIM in construction management of railway tunnel by virtual technology Application of BIM in construction management of railway tunnel by virtual technology. IOP Conference Series: Earth and Environmental Science, 153(3). Power System Technology. DOI: https://doi.org/10.1088/ 1755-1315/153/4/042012

Costin A., Adibfar A., Hu H., Chen S. S. (2018), Building Information Modeling (BIM) for transportation infrastructure - Literature review, applications, challenges, and recommendations. Automation in Construction, 94: 257-281. DOI: https://doi.org/10.1016/j.autcon.2018.07.001
Doyon L. R., Sheehan T. V., Zagor H. I. (1971), Classroom Exercises in Applying the Delphi Method for Decision-Making. Socio-Economic Planning Sciences 5(4): 363-375. DOI: https://doi.org/10.1016/oo380121(71)90022-X

Enshassi A., Ayyash A., Choudhry R. M. (2016), BIM for construction safety improvement in Gaza strip: awareness, applications and barriers. International Journal of Construction Management, 16(3), 249-265. DOI: https://doi.org/10.1080/15623599.2016.1167367

Ferrandiz J., Banawi A., Peña E. (2018), Evaluating the benefits of introducing "BIM" based on Revit in construction courses, without changing the course schedule. Universal Access in the Information Society, 17(3), 491-501. DOI: https://doi.org/10.1007/ s10209-017-0558-4

Galieva A. B., Alekhin V. N., Antipin A. A., Gorodilov S. N. (2018), Defects search during the inspection of civil and industrial buildings and structures on the basis of laser scanning technology and information modeling approach (BIM). MATEC Web of Conferences 146. DOI: https://doi.org/10.1051/ matecconf/201814601007

Gani N. A., Assarudeen M. S. N. (2012), A New Operation on Triangular Fuzzy Number for Solving Fuzzy Linear Programming Problem. Applied Mathematical Sciences 6: 525-532. DOI: https://doi. org/10.13140/2.1.3405.8881

Garyaeva V. (2018), Formation of competitive skills of engineers in the field of BIM technologies. MATEC Web of Conferences 170: 1-4. DOI: https://doi.org/10.1051/ matecconf/201817001077

Gottems L. B. D., Carvalho E. M. P., Guilhem D., Pires M. R. G. M. (2018), Good practices in normal childbirth: reliability analysis of an instrument by Cronbach's Alpha. Revista Latino-Americana de Enfermagem, 26, e300o. DOI: https://dx.doi.org/ 10.1590/1518-8345.2234.3000

Herr C. M., Fischer T. (2019), BIM adoption across the Chinese AEC industries: An extended BIM adoption model. Journal of Computational Design and Engineering 6(2): 173-178. DOI: https://doi.org/ 10.1016/j.jcde.2018.06.001

Hosseini M. R., Azari E., Tivendale L., Banihashemi S., Chileshe N. (2016), Building Information Modeling (BIM) in Iran: An Exploratory Study. Journal of Engineering, Project, and Production Management, 6(2), 78-89. DOI: 10.32738/JEPPM. 201607.0002

Hosseini M. R., Azari E., Tivendale L., Chileshe N. (2018), Barriers to Adoption of Building Information Modeling (BIM) in Iran: Preliminary Results. Engineering, Project and Production Management, 384-394. DOI: https://doi.org/10.32738/ceppm. 201509.0038 
Hsu Y. L., Lee C. H., Kreng V. B. (2010), The Application of Fuzzy Delphi Method and Fuzzy AHP in Lubricant Regenerative Technology Selection. Expert Systems with Applications 37(1): 419-425. DOI: https://doi.org/10.1016/j.eswa.2009.05.068

Ismail N. A. A., Chiozzi M., Drogemuller R. (2017), An overview of BIM uptake in Asian developing countries. AIP Conference Proceedings. DOI: https://doi.org/10.1063/1.5011596

Jahanshahi A., Jahanianfard D., Mostafaie A., Kamali, M. (2019), An Auto Regressive Integrated Moving Average (ARIMA) Model for prediction of energy consumption by household sector in Euro area, 7(2), 151-164. DOI: https://doi.org/10.3934/energy. 2019.2.151

Jahanshahi A., Kamali M., Khalaj M., Khodaparast Z. (2019), Delphi-based prioritization of economic criteria for development of wave and tidal energy technologies. Energy 167: 819-827. DOI: https://doi.org/10.1016/j.energy.2018.11.040

Jung W., Lee G. (2015), The Status of BIM Adoption on Six Continents. International Journal of Civil, Structural, Construction and Architectural Engineering, 9(5), 406-410. Retrieved from: https://media. thebimhub.com/user_uploads/the-status-of-bimadoption-on-six-continents_1.pdf

Kamali M., Alesheikh A. A., Alavi Borazjani S. A., Jahanshahi A., Khodaparast Z., Khalaj M. (2017), Delphi-AHP and Weighted Index Overlay-GIS Approaches for Industrial Site Delphi-AHP and Weighted Index Overlay-GIS Approaches for Industrial Site Selection Case Study: Large Extractive Industrial Units in Iran. Journal of Settlements and Spatial Planning, 8(2), 99-105. DOI: 10.24193/JSSP.2017.2.03

Kamali M., Costa M. E., Capela I. (2017), Nitrate Removal and Nitrogen Sequestration from Polluted Waters Using Zero-Valent Iron Nanoparticles Synthesized under Ultrasonic Irradiation. In: Shahidul-Islam (ed.) Advanced Materials for Wastewater Treatment, 479-505. Hoboken, NJ, USA. John Wiley \& Sons, Inc. DOI: https://doi.org/10.1002/9781119 407805.ch13

Kaneta T., Furusaka S., Deng N. (2017), Overview and problems of BIM implementation in Japan. Frontiers of Engineering Management, 4(2), 146-155. DOI: https://doi.org/10.15302/J-FEM-2017007

Khanzadi M., Sheikhkhoshkar M., Banihashemi S. (2018), BIM applications toward key performance indicators of construction projects in Iran. International Journal of Construction Management. DOI: https://doi.org/10.1080/15623599.2018.1484852

Kivits R. A., Furneaux C. (2013), BIM: Enabling sustainability and asset management through knowledge management. The Scientific World Journal, 2013. DOI: https://doi.org/10.1155/2013/983721
Krivonogov, A., Zakharova, G., Kruglikov, S., Plotnikov, S. (2018), Implementation of BIMtechnologies in the educational program of the architectural university. MATEC Web of Conferences. 146. 01001. DOI: https://doi.org/10.1051/matecconf/ 201814601001

Liao L., Teo A. E. L., (2019), Managing critical drivers for building information modelling implementation in the Singapore construction industry: an organizational change perspective. International Journal of Construction Management, 19(3), 240-256. DOI: https://doi.org/ 10.1080/15623599.2017.1423165

Lin Y. C., Lin C. P., Hu, H. T., Su Y. C. (2018), Developing final as-built BIM model management system for owners during project closeout: A case study. Advanced Engineering Informatics, 36, 178-193. DOI: https://doi.org/10.1016/j.aei.2018.04.001

Maimaiti, P, Feng Sen L., Aisilahong G., Maimaiti R., Yun W. Y. (2019), Statistical analysis with Kruskal Wallis test for patients with joint contracture. Future Generation Computer Systems 92: 419-423. DOI: https://doi.org/10.1016/j.future.2018. 10.024

Migilinskas D., Pavlovskis M., Urba I., Zigmund V. (2017), Analysis of problems, consequences and solutions for BIM application in reconstruction projects. Journal of Civil Engineering and Management, 23(8), 1082-1090. DOI: https://doi.org/10.3846/ 13923730. 2017.1374304

Migilinskas D., Popov V., Juocevicius V., Ustinovichius L. (2013), The Benefits, Obstacles and Problems of Practical Bim Implementation. Procedia Engineering, 57, 767-774. DOI: https://doi.org/10. 1016/j.proeng.2013.04.097

Mirarchi C., Pavan A., De Marco, F., Wang X., Song Y. (2018), Supporting Facility Management Processes through End-Users' Integration and Coordinated BIM-GIS Technologies. International Journal of Geo-Information, 5(7), 191. DOI: https:// doi.org/10.3390/ijgi7050191

Mohammad W. N. S. W., Abdullah M. R., Ismail S., Takim R. (2018), Building information modeling (BIM) adoption challenges for contractor's organisations in Malaysia. AIP Conference Proceedings. DOI: https://doi.org/10.1063/1.5055550

Mostafavi N., Farzinmoghadam M., Hoque $\mathbf{S}$. (2015), Envelope retrofit analysis using eQUEST, IESVE Revit Plug-in and Green Building Studio: a university dormitory case study. International Journal of Sustainable Energy, 34(9), 594-613. DOI: https://doi.org/10.1080/14786451.2013.848207

Muller M., Loures E., Mendes R., Canciglieri O., Freitas M. D. C. D., Frederico G. F. (2016). Developing BIM culture in a university -past and future steps. Advances in Transdisciplinary Engineering, 4, 
358-367. DOI: https://doi.org/10.3233/978-1-61499703-0-358

Okoli C., Pawlowski S. D. (2004), The Delphi Method as a Research Tool: An Example, Design Considerations and Applications. Information and Management 42(1): 15-29. DOI: https://doi.org/ 10.1016/j.im.2003.11.002

Pavlovskis M., Migilinskas D., Antuchevičiene J., Urba I., Zigmund V. (2017), Problems in reconstruction projects, BIM uses and decision-making: Lithuanian case studies. Procedia Engineering, 208, 125128. DOI: https://doi.org/10.1016/j.proeng.2017.11.029 Pinto F. S. T., Fogliatto F. S., Qannari E. M. (2014), A method for panelists' consistency assessment in sensory evaluations based on the Cronbach' s alpha coefficient. Food Quality and Preference 32(A): 41-47. DOI: 10.1016/j.foodqual.2013.06.006

Pocobelli D. P., Boehm J., Bryan P., Still J., Grau-Bové J. (2018), BIM for heritage science: a review. Heritage Science, 6(1), 23-26. DOI: https://doi.org/10.1186/s40494-018-0191-4

Rehm M., Ade R. (2013), Construction costs comparison between green and conventional office buildings. Building Research and Information, 41(2), 198-208. DOI: https://doi.org/10.1080/o9613218. 2013.769145

Reizgevičius M., Ustinovičius L., Cibulskiene D., Kutut V., Nazarko L. (2018), Promoting Sustainability through Investment in Building Information Modeling (BIM) Technologies: A Design Company Perspective. Special Issue Sustainability in Construction Engineering. DOI: https://doi.org/ 10.3390/su10030600

Rodrigues F., Teixeira J., Matos R., Rodrigues H. (2019), Development of a Web Application for Historical Building Management through BIM Technology. Advances in Civil Engineering. DOI: https://doi.org/10.1155/2019/9872736

Sánchez-Lezama A. P., Cavazos-Arroyo J., Albavera-Hernández C. (2014), Applying the Fuzzy Delphi Method for determining socio-ecological factors that influence adherence to mammography screening in rural areas of Mexico, Cadernos de Saúde Pública 30(2): 245-258. DOI: http://dx.doi.org/10.1590/o102311 Xooo25113

Siebelink S., Voordijk J. T., Adriaanse A. (2018), Developing and Testing a Tool to Evaluate BIM Maturity: Sectoral Analysis in the Dutch Construction Industry. Journal of Construction Engineering and
Management, 144(8). DOI: https://doi.org/10.1061/ (ASCE)CO.1943-7862.0001527

Succar B. (2009), Building information modelling framework: A research and delivery foundation for industry stakeholders. Automation in Construction, 18(3), 357-375. DOI: https://doi.org/10.1016/j.autcon. 2008.10.003

Tahriri F., Mousavi M., Hozhabri Haghighi S., Dawal S. Z. (2014), The Application of Fuzzy Delphi and Fuzzy Inference System in Supplier Ranking and Selection. Journal of Industrial Engineering International 10: 66. DOI: https://doi.org/10.1007/ s40092-014-0066-6

Takim R., Harris M., Nawawi A. H. (2013), Building Information Modeling (BIM): A new paradigm for quality of life within Architectural , Engineering and Construction (AEC) industry. Procedia - Social and Behavioral Sciences, 101, 23-32. DOI: https://doi.org/ 10.1016/j.sbspro.2013.07.175

Wei T., Chen G., Wang J. (2017), Application of BIM Technology in Building Water Supply and Drainage Design Application of BIM Technology in Building Water Supply and Drainage Design. Earth and Environmental Science 100, 8-13. DOI: https://doi. org/10.1088/1755-1315/100/1/012117

Yousuf M. I. (2007), Using Experts' Opinions through Delphi Technique - Practical Assessment, Research and Evaluation. Practical Assessment, Research \& Evaluation 12(4): 1-8. Retrieved from: http:// pareonline.net/getvn.asp? $\mathrm{v}=12 \& \mathrm{n}=4$.

Zhang B., Chen R. (2018), Nonlinear Time Series Clustering Based on Kolmogorov-Smirnov 2D Statistic. Journal of Classification 35(3): 394-421. DOI: 10.1007/s00357-018-9271-0

Zhang J., Long Y., Lv S., Xiang Y. (2016), BIMenabled Modular and Industrialized Construction in China. Procedia Engineering, 145, 1456-1461. DOI: https://doi.org/10.1016/j.proeng.2016.04.183

Zhao L., Zhai S., Chen F., Ji F. (2017), Research on the Application of BIM Technology in Tunnel Project Construction. Proceedings of the 20th International Symposium on Advancement of Construction Management and Real Estate, 153, 391-404. DOI: https://doi.org/10.1007/978-981-10-0855-9_34 